\title{
The Annual of the British School at Athens
}

http://journals.cambridge.org/ATH

Additional services for The Annual of the British School

at Athens:

Email alerts: $\underline{\text { Click here }}$

Subscriptions: Click here

Commercial reprints: $\underline{\text { Click here }}$

Terms of use : $\underline{\text { Click here }}$

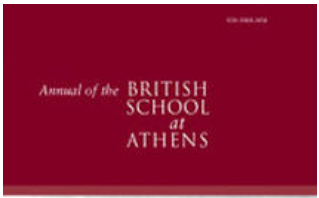

\section{I.-Excavations At Sparta, 1908 § 3.-The Pottery}

\section{J. P. Droop}

The Annual of the British School at Athens / Volume 14 / November 1908, pp 30 - 47

DOI: 10.1017/S0068245400003130, Published online: 18 October 2013

Link to this article: http://journals.cambridge.org/abstract_S0068245400003130

How to cite this article:

J. P. Droop (1908). I.-Excavations At Sparta, 1908 § 3.-The Pottery. The Annual of the British School at Athens, 14, pp 30-47 doi:10.1017/S0068245400003130

Request Permissions : $\underline{\text { Click here }}$ 


\title{
LACONIA.
}

\section{1.-EXCAVATIONS AT SPARTA, 1908.}

\section{§ 3.-The PotTery.}

\author{
(Plates III., IV.)
}

THE excavations of 1908 more than fulfilled expectations in the amount of light that was shed on the later history of the Spartan pottery, so that it is now possible to write an account of the development and decline of the Laconian fabric; which account, beginning in the ninth or tenth century, ends with the latter half of the fourth, when the pottery loses its local characteristics in the various styles that appear to have been common to the whole Greek world during the last three centuries before the Christian Era.

On account of the entirely local character of the Spartan pottery, and for the sake of clearness, so as best to present its development, it has been decided to treat of the style subsequent to the Geometric Age in six periods, and to call them Laconian I., II., III., IV., V., and VI.

The distinction thus drawn between the Geometric styles of Sparta and the Laconian style is justifiable because, although the fabric ${ }^{1}$ throughout is unbroken, the impulse to which the later style owes its origin is to be looked for, not in the preceding Geometric style, but in that influence from Asia Minor, which apparently modified and broke up the various Geometric styles throughout Greece about the beginning of the seventh century.

\section{Laconian I. (circ. 700-625).}

The pottery of the first stage of the Laconian style lay beneath the sand over the whole area covered by it, and immediately above the 
Geometric pottery. This ware was discussed last year under the title 'Orientalising Style B.' There is little to add to that account, except to note that the shape there given for the typical skyphos ${ }^{1}$ should have a more pronounced rim, as is seen in Fig. I, which gives the true shape. Other sherds of the style are shewn in Fig. 2, of which it may be said that the black cross design with purple circles $(d)$ appears almost as regularly on the base as the dot and square pattern $(g, h, i)$ on the rim. In addition to the skyphos and the plates described last year ${ }^{2}(a, b, f)$, small bowls $(h)$ with an offset lip, two horizontal handles on the belly, and sometimes a

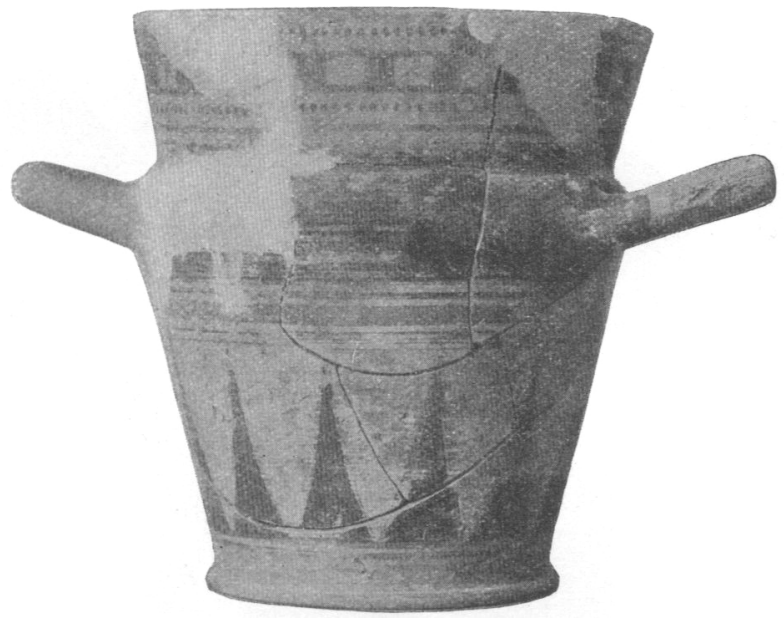

Fig. I. - L,aconian I. (SCale I : 2.)

low foot, are not infrequent ; while fragments of tiny handleless bowls, and of high wide-brimmed cups with one small circular handle at the brim are met with less often. The lakaina ${ }^{3}(d)$ is rarely met with in this style, although it is frequent in the ware called last year ' Orientalising Style A.' The neck is not yet very high, and does not spread out, and the belly, not clearly seen in the illustration, is now unpainted, while the base resembles

1 B.S.A. xiii. p. 129, Fig. $7, e$.

2 Loc. cit. Fig. $7, f$, described misleadingly as bowls.

${ }^{3}$ This name ( $\lambda$ ákalva) I propose to give to the vase-shape illustrated B.S.A. xiii. p. I29, Fig. $7, c$. The name is given by $A$ thenaeus $(A t h . x i, 484)$ to a drinking vessel, so-called either because it was made of Laconian clay, or because it had a shape much affected in Laconia. The shape to which I would apply it is very frequent in, if not confined to, the Laconian style, is not suited by any name in use, and may well have been used for drinking. 
exactly that of the other bowls (h). It may be remarked here that the small vases of style $A$, of which the decoration consists of purple and white lines applied to a black ground, continued to be made with no discernible development all through the period occupied by Laconian I., II., III., and IV. Later they are not found, though the miniature vases ${ }^{1}$ continue, albeit perhaps in lesser quantities, till late in the fifth century. ${ }^{2}$

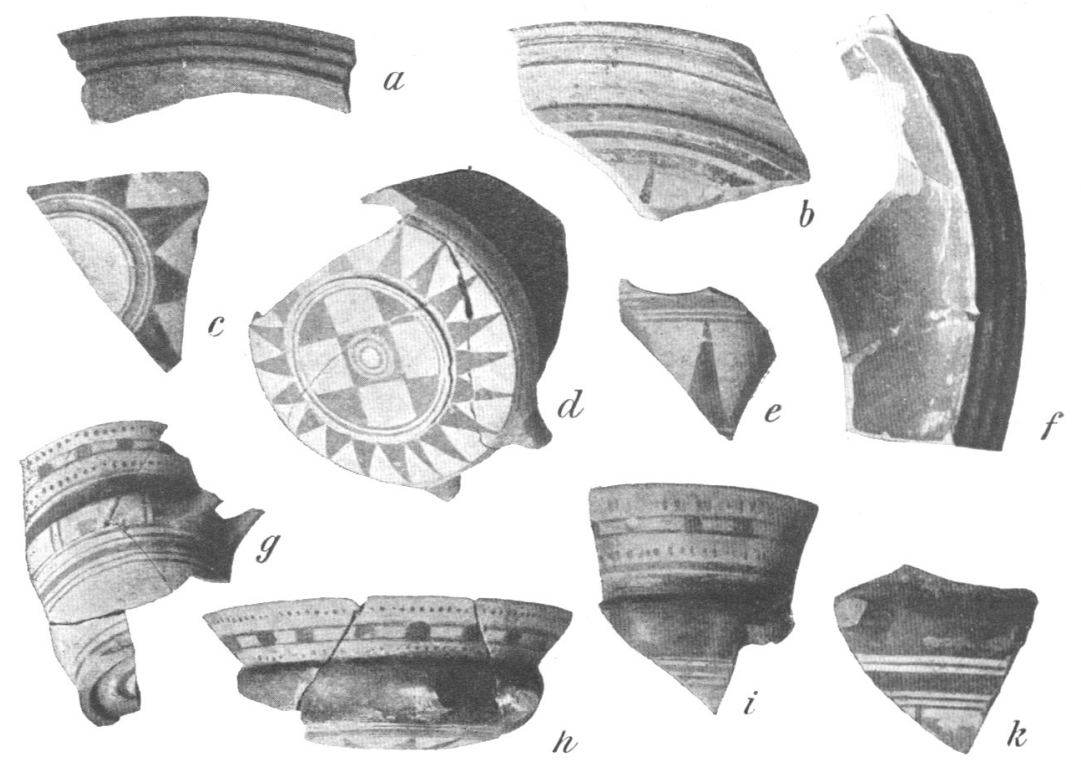

Fig. 2.-LaConian I. (SCALE $2: 5$.

Laconian II. (circ. 625-600).

It is unfortunate that it was not until very late in the excavation that the best of the vase fragments, which we are able to class as Laconian II., were found, so that the sufficient illustration here of the style has been prevented. It was felt even earlier that some links must exist between the simplicity of Laconian I. and the full development of Laconian III. It is the discovery in that region, which received the last deposits before the

I B.S.A. xiii. p. 129 , note 2.

${ }^{2}$ There are some sherds of Laconian I. in the Pinacothek at Munich. Berlin Antiquarium I647, and Louvre, $\mathrm{E} 674$, also belong to this style. 
laying down of the sand, namely the region which stretcles north-east from the earlier temple along the northern edge of the paved area, ${ }^{1}$ of pieces likely from their style to fill the gap, that has allowed us to place with them in this category other pieces, about which we had hesitated so long as the evidence of style had not received the support of stratification. To this class, then, we can assign the first appearance of the ornament (Fig. 3, c, $d$; Fig. 10, $e$ ) of black pointed leaves springing from a purple branch, which at this date is as regular as the square and dot pattern round the lip of the

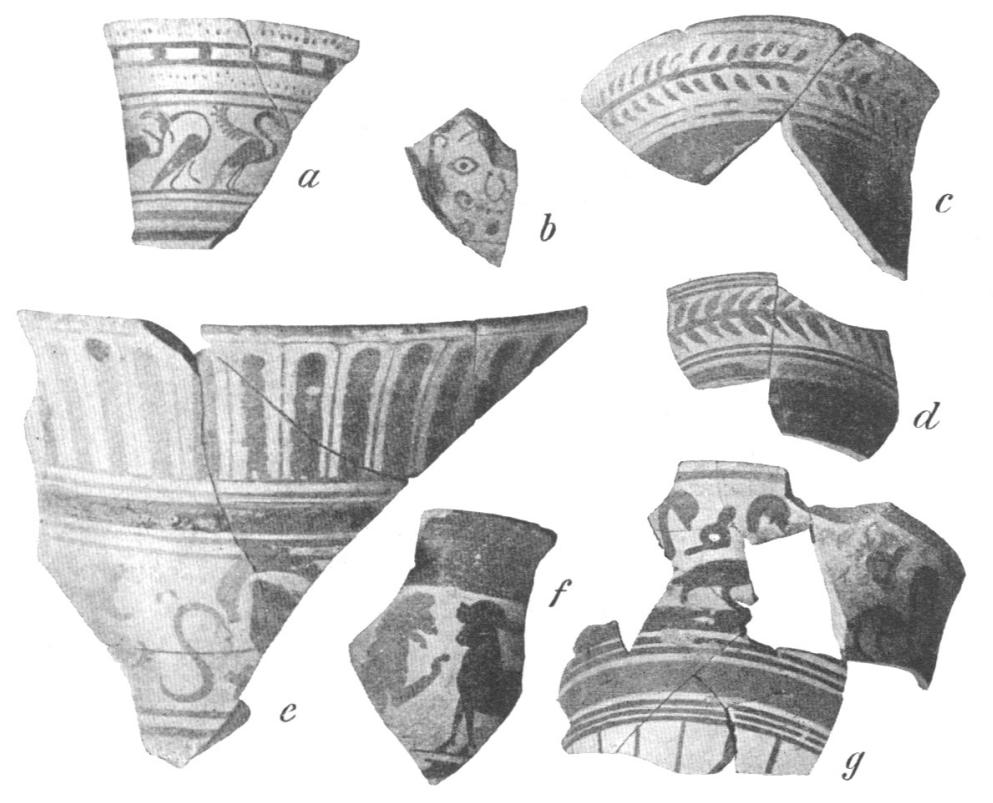

Fig. 3.-Laconian II. (Scale $2: 5$. )

lakaina, a shape that is now fully developed with a spreading rim, and regularly shews a pattern of narrow rays up the belly. Here also the tongue pattern first comes on the scene (Fig. 3,e), and the pomegranate, in an early form that recalls an ornament of the Geometric pottery. ${ }^{2}$ The exact period of the four sherds (Fig. $3, a, e, f, g$ ), which shew birds and animals in silhouette without incisions is a question; for in point of fact they were found in company with a mass of Laconian III. ware, thrown out

$$
{ }^{1} \text { Cf. Plan, Plate I. } \quad 2 \text { B.S.A xiii. p. 120, Fig. } \mathrm{i}, r \text {. }
$$


at a later date; but there is no proof that they were made at the same period, and indeed they look earlier, so that to class them with Laconian II. seems not unfair. That this is correct at least for $e$ is clear from a method used on vases that are certainly of this period (and I think only used on them) of applying the purple pigment very thickly, and, I suspect, of baking it particularly lightly. The resulting colour is very fresh and extremely friable, while both earlier and later the purple is thinner and duller. This process is found in a vase, of which part was published last year, ${ }^{1}$ prematurely, as it turned out, for many other pieces of the vase were discovered at the very end of last season in surroundings that date it clearly to the last years of the seventh century. Such a date is confirmed by the style of the new fragments, which shew the so-called lotus pattern and a handle palmette, both characteristic of the next period, but both in very early form. Unfortunately we are obliged to hold over the full publication of this vase (a rather large lakaina), as also of the object, of which the Gorgoneion shewn in Fig. 3, $b$, is a part. This is a round hollow piece of pottery open at both ends, about $108 \mathrm{~m}$. high, with two pairs of holes pierced in the lower rim. It is not certain if the circle was complete, but in any case its diameter ( $\circ 90 \mathrm{~m}$.) makes it too small to be an onos, which at first it suggests. Besides the row of Gorgon heads separated by a chequer pattern, to which the sherd illustrated belongs, this strange object is decorated gaily with a tongue pattern and band of squares round the upper and lower rims respectivcly, while between come a strange key pattern and a band of chevrons, purple all through alternating with brown and black.

It is at this time also that the kylix is first found, though it does not seem to have become a favourite shape until the next period. It has always an offset rim, and seems to be a natural development from the bowl of Laconian I. (Fig. 2, $h$ ). The quite short stem is slipped (Fig. 10, $c, d$ ) and painted with black and purple rings, though black stems (id. $e$ ) are of course also found.

Through this period probably, and into the next, the early form of plate with a ribbed rim painted black continued (Fig. 2, $a, b, f$ ), of which one specimen of this date has a dedicatory inscription in white paint. A step, however, towards the development of the next period is here found in three plates, one of which (a vase that also has a dedicatory inscription 
painted in white), keeping the channelled rim, has it covered with slip, while the others have smooth rims decorated with a pattern of chevrons and wedges respectively, and are slipped both inside and out.

Two other vases must be mentioned, the inclusion of which in this period is backed by the evidence both of style and stratification. One is a cup with a ring handle and wide spreading lip that recalls the shape found in Laconian I. This cup shews one of the first examples of the lotus pattern, and has also a tongue pattern and a row of zigzags (cf. Fig. 4,o), both most characteristic of the next period, but its slightly earlier date may be guessed from the pattern on the base, which is that of Laconian I. (Fig. 2, $d$ ) in all its simplicity. The other vase, of which only a fragment remains, was probably of similar shape, and shews on the outer rim the usual early dots and squares, but on the inner a row of single purple tongues, that link it to some good kylix rims of the subsequent period.

\section{Laconian III. (circ. 600-550).}

The bulk of the ware of this period was found in the deposit immediately above the sand to the north and south of the later temple. ${ }^{1}$ It is in this period that the style reaches its highest level, embodying a wealth of patterns that is relatively great. Plates, lakainai, oinochoai, and kylikes form the bulk of the material, which it will be best to discuss in order.

In place of the black channelled rim, which probably still partially survived, the majority of plates shew a smooth slipped rim decorated with a tongue pattern (Fig. $4, r, s$ ), a wedge pattern, or more rarely with a zigzag (Fig. 4,o), or a lotus (Fig. 4, $q$ ). The under side of the broad rim is black, and, as earlier, the outside of the plate has a pattern of rays, either single or double (Fig. 4, w), stretching up to the purple band that borders the black of the rim. But the fine plate (Fig. 4,o) has a pattern of alternate rays (cf. Fig. 4,a), and the inside is not black but slipped, and shews traces of a beast scene. The rule for the central decoration is a rosette surrounded by purple and black circles, while the base has generally a Gorgoneion in a ring of chevrons or dots (Fig. $4, t, u$ ).

There is little doubt that the simple style of lakaina with a broad

${ }^{1}$ Cf. 'The deposit immediately succeeding the building of the later temple.' Plate II. 


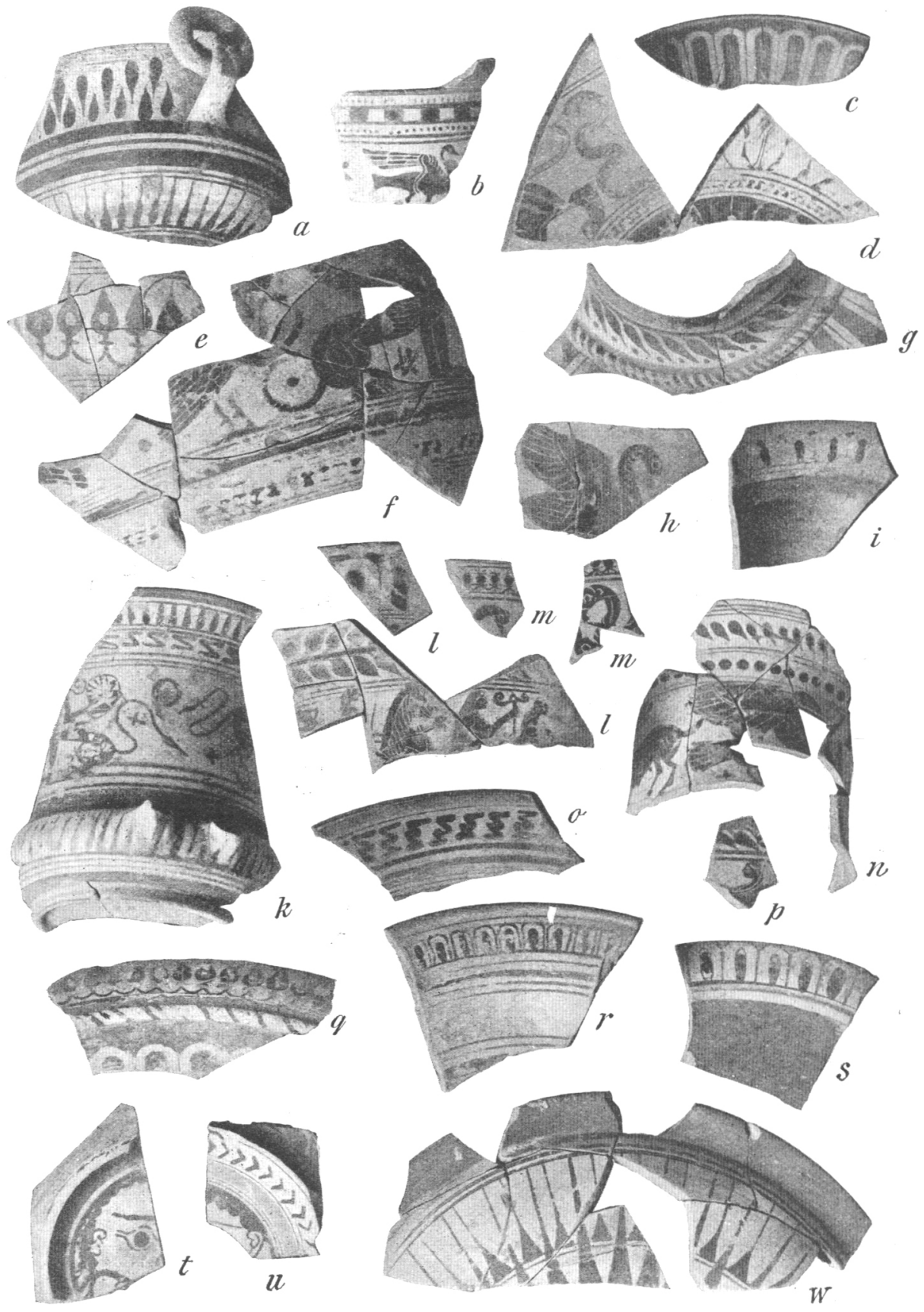

Fig. 4.-Laconian III. (Scale $2: 5$. ) 
black band on the lower part of the high neck continued, but the typical lakaina of this period is a more ornate affair. Eagles and deer and lions, sirens with an odd headdress (cf. Fig. 8, $g$; B.S.A. xiii. p. I 34, Fig. (O, c), sphinxes, and cocks are found, often arranged heraldically, and sometimes with a lotus or palmette between (cf. Fig. 8, $f, h$ ). Crosses frequently (Fig. 4, $k, n$ ), and rarely rosettes are found in the field, while in one case a lizard separates the figures. Frequently the outer rim is black, though rows of dots and dashes are also found here (Fig. $4, k, n$ ), but on the inner rim a tongue pattern (Fig. 4, $i$ ) is the rule, above a purple band, while narrow rays continue to be the stock decoration for the low belly (Fig. 4, $k$ ); though finer examples sometimes shew here a lotus, or a leaf pattern, and a lotus, a tongue, a leaf (Fig. 4, l,p), or a pomegranate pattern (Fig. $4, m$ ) on the rim. The base is generally ornamented with circles in black and purple, sometimes enclosing a flying eagle. The better specimens of the lakaina have also handle palmettes like those familiar on the kylix (cf. Fig. $7, g$ ). A particularly fine example is that shewn in Fig. 4, $l$, of which another fragment makes it clear that the scene was arranged symmetrically. All the figures, as is usual at this period, are incised, and purple is used over black for the hair and the horses' manes.

Of oinochoai ${ }^{1}$ we have many fragments, and sufficient of one to allow of its reconstruction (Fig. 5). The height of this vase is $23 \mathrm{~m}$.

The handles are very obviously imitations of metal work, being oblong in section and channelled on the outside, while on the inner rim, on either side of the handle, several examples shew a button representing the bolt used for its attachment in the metal original. In this position is frequently found a lion's head, and in one case a woman's, modelled in relief, while the relief palmette, usual at the lower attachment of the handle, served in the bronze original a similar purpose. The palmettes are slipped and picked out with black, the buttons are black with dots in white, and the heads at this period are regularly slipped with hair in purple and eyes in black. The trefoil lip is invariably black, while on the neck is a network of pomegranates (Fig. 5), often with a purple cross at the junctures, or else a leaf pattern (Fig. $4, g$ ). A ridge painted with slanting lines as a rule separates the neck from the shoulder, which

${ }^{1}$ One fragment was said last year (B.S.A. xiii. p. 132) to be without slip. This was a mistake, the only odd point about the vase being the grey colour assumed by the clay. 
is either rounded or flat, meeting the belly at an angle (Fig. 5), and is decorated most often with a tongue pattern (Fig. 4. $g$ ), though the lotus (Fig. 5) is also found, and one piece has an elaborate row of lotus palmettes. ${ }^{1}$ The frieze invariably presents the same variety of figures as that of the lakaina; the vase shewn in Fig. 5 has on each

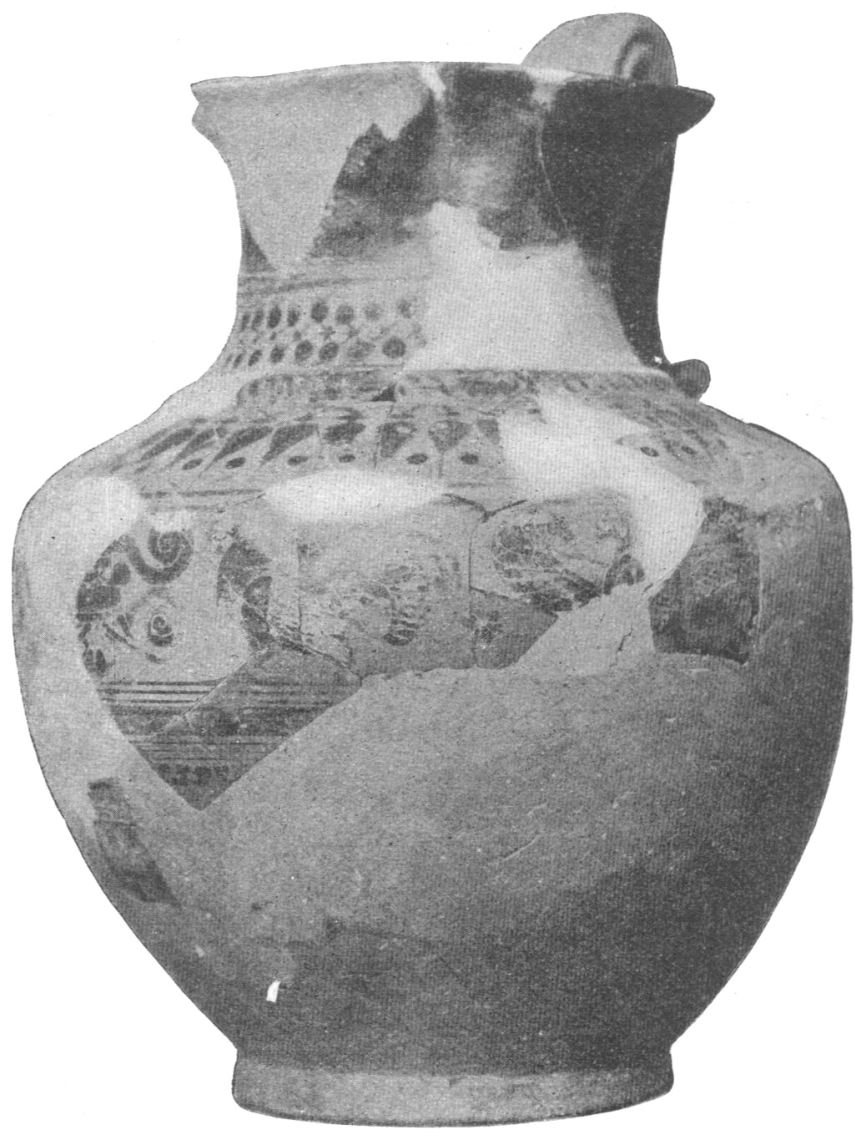

Fig. 5.-Laconian III. (Scale $I: 2$.

side a cock, a sphinx, and a flying eagle arranged symmetrically with a palmette as centre. Below the frieze and above the rays, single or double, that reach from the base, come lines both black and purple, a

${ }^{1}$ Cf. Rev. Arch. 1907, tom. ix. p. 384, Fig. 7, top right-hand corner. 
$z$ pattern (Fig. $4, f$ ) is frequent, and sometimes a row of lotus (Fig. 4,e) is found. The favourite alternation of thick and thin lines (Fig. 4, $f$; Fig. 5) should be noticed as an inheritance from the Geometric style. ${ }^{1}$ The base generally has a rosette.

The stem of the kylix, usually but not always short, is now more ornate than during the preceding period, though the black variety is also found. Below rings of black and purple a pattern of tongues ${ }^{2}$ stretches down to the sharp edge of the splayed foot. The favourite style of decoration for the interior as well as for the exterior of the kylix was, as numerous fragments attest, not unlike that preferred on other shapes, namely a series of figure friezes with birds and beasts alternating with bands of patterns, among which the lotus and pomegranate predominated. A good example is shewn in Fig. 4, $d$, where, round a black incised rosette (?) picked out with purple, is seen a $z$ pattern, outside which is a scene that must have been oddly unequal. To the left are the hind-quarters of a lion, incised, with purple on the haunch. Behind is an upright bearded snake, also incised, with a series of purple dots representing his scales. To the right are seen the feet of a pair of horses facing, between which is a water-fowl. The scale of the horses is so small as to make 'it a certainty that they had riders. What is unusual here is not the principle of isocephalism but the disconnection between the two parts of this continuous frieze. A decorative kylix rim is shewn in Fig. 4 , $c$, the outside of which has a pattern of single tongues purple and black, but perhaps the best fragment that we have recovered is the sinall kylix with the cocks (Fig. 6). The skill lavished on the birds is in striking contrast with the careless haste with which the tongue

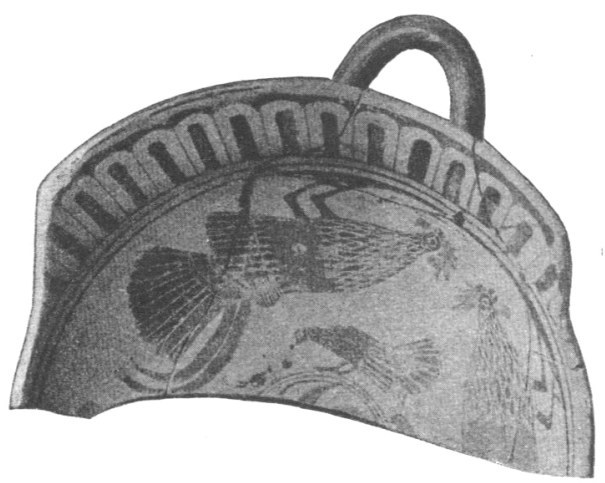

Fig. 6. - Laconian III. (SCAle I : 2.) pattern was painted. The combs and middles of the cocks are purple, and dashes of the same colour decorate their tails. The ant and snail

${ }^{1}$ B.S.A. xiii. p. 120, Fig. 1, $e$.

${ }^{2}$ Cf. Böhlau, Aus ionischen und italischen Necropoien, Taf. x. 3. 
are black, and a pattern of single pomegranates ornaments the outer rim. The kylix shown in Plates III., IV. belongs probably to the latter end of this period, for it is the earliest vase found at Sparta (since the earlier Geometric Age) to shew the unslipped clay, though to the very small extent of two lines on the inner rim. The vase stands about . $105 \mathrm{~m}$. high, of which the stem accounts for $054 \mathrm{~m}$., and in diameter the bowl varies from $168 \mathrm{~m}$. to $155 \mathrm{~m}$. The four winds are the readiest interpretation of these winged men in rapid motion, but that leaves unexplained the presence of the tree, and the bird-headed monkey seated on a stool. It must be noted that the work both of potter and painter was careless in the extreme; and the latter had no proper appreciation even here of the opportunities afforded by the kylix form for the presentation of a scene, for the interior is treated as one wide frieze. Fragments, however, of another kylix shew two stags facing each other with an exergue above and below, filled with a palmette ornament.

Remains of small bowls of simple decoration are fairly numerous, one of which with an old ring in its handle is shown in Fig. 4, $a$.

Laconian IV. (circ. 550-500).

The bulk of the pottery of this and the next period was found to the east of the hieron wall in the region round about the point marked $\mathrm{A}$ on the plan. ${ }^{1}$ With the middle of the sixth century began the decay of the Laconian style, of which the symptoms are to be looked for in the gradual degeneration of the patterns, the inferior quality of the slip, and in a partial disuse of slip. Comparison, for instance, may be made between the Gorgoneion, the tongue pattern, and the rays that decorate the plates of Laconian III. (Fig. 4, $s, t, u, w$ ) and the corresponding ornaments of Laconian IV. (Fig. $7 e, f$ ), but unfortunately the inferior quality of the slip cannot be seen in a photograph. No particular description of this phase is required, for there is no marked change other than is comprised in the word degeneration. Four kylix fragments are shewn (Fig. $7, b, c, h, i$ ), which dispense with slip on one side. Parts of a jug, a bowl, and a lakaina of this period are also illustrated (Fig. $7, a, d, g$ ). It should be noticed that the 
black paint, which in the earlier periods is very good, with at times almost a blue shade, and hardly gleaming, now often becomes a shiny black when it is not brown through washiness.

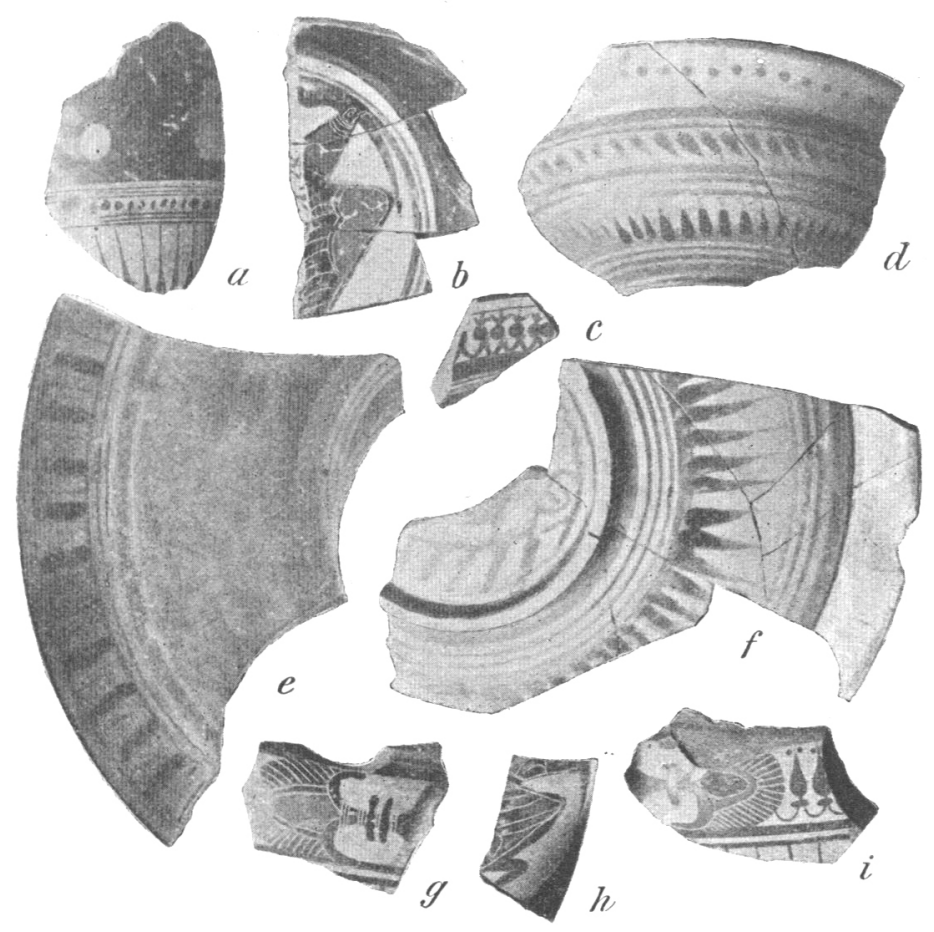

Fig. 7.-Laconian IV. (Scale $2: 5$.)

Laconian V. (circ. 500-425).

In this period degeneration has advanced, for the use of slip has been entirely abandoned, and purple, too, has become rare as ornament, though it is still freely used for figure details, for which white paint is also now much employed, an innovation in this connection that may be illustrated by Fig. $8, l$, where the scales of the snakes are represented by white dots, not purple as in Laconian III. (Fig. 4, $d$ ). In this period, or at the close perhaps of the foregoing, is introduced a pattern of crescents, which becomes a favourite. ${ }^{1}$ The early base pattern is preserved, as also the

${ }^{1}$ Cf. the Cassel kylix (Arch. Anz. 1898, p. I89) and that in the National Museum at Athens, (J.H.S. 1908, p. I77, Fig. 2, b). Both these fall, I think, into Laconian IV. 
rosette that is common on the base of the oinochoai of Laconian III. and IV. (Fig. $8, i, n$ ), but the purple circles have been abandoned. Purple, however, is still used on the plate rim, where the tongue pattern has been

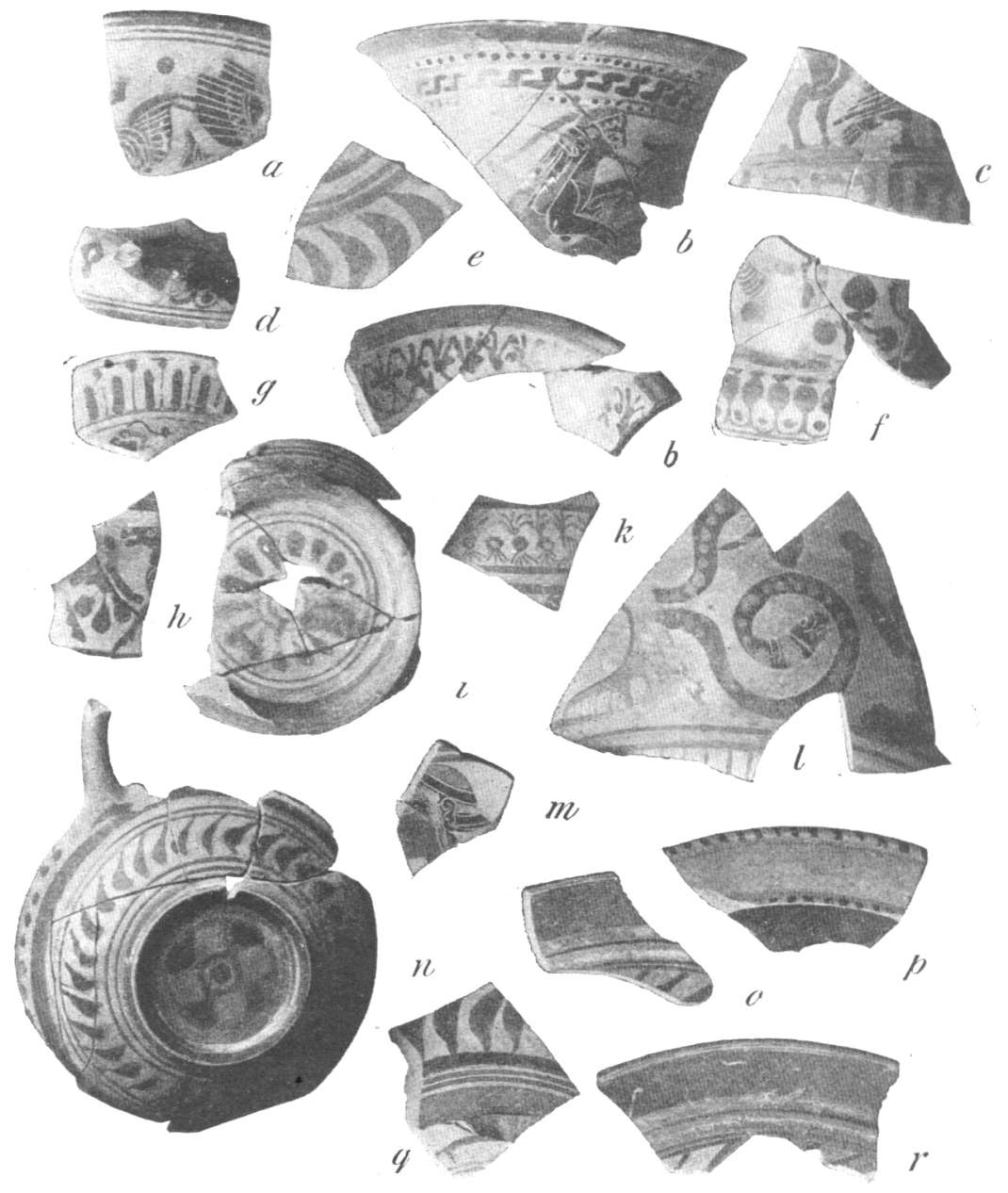

Fig. 8.-Laconian V. (Scale $2: 5$.)

laid aside in favour of two ridges crossed by slanting lines (Fig. 8, p), while on the outside, rays are supplanted by the new crescent pattern (Fig. 8, $o, q, r$ ). The great degeneration of the lotus and pomegranate can be seen in Fig. $8, b, d, f, k$, and also on those sherds published last year, 
which belong to this period. ${ }^{1}$ It will be seen that no change was made in the method of decorating oinochoai, and the same heraldic groups of birds and beasts continue on lakainai (Fig. $8, a, b, c, f, g, h, l$ ). It is regrettable that no more is preserved of the kylix shown in Fig. $8, m$, for it must have been a very good and careful piece of work, to be dated probably to the early part of this period.

The exact date at which the form shown in Fig. Io, $a, b$ was generally adopted for the stem of the kylix is uncertain. The evidence of the finds leads to the supposition that the introduction of ridges round the stem, and a rounded edge to the foot, belongs to the period covered by Laconian IV., but the number of examples of this form found with the pottery of a later date suggest that it was in general use at least to the close of the fifth century. It is very natural that a degenerated style should continue the tradition of a decorated stem by the substitution of an unglazed band of channelled rings for the black and purple lines of the vigorous period. ${ }^{2}$ This later form appears to be a particularly Spartan feature, which, when seen on an Attic kylix, is, I believe, in most cases accompanied by a sufficiency of other signs to make it probable that the vase is an imitation of Laconian ware. ${ }^{3}$

\section{Laconian VI. (circ. 425-350).}

The bulk of the pottery of this period was found in the region east of the hieron wall, and bordering on the old bed of the mill stream. A complete abandonment of purple colour and of figures marks the latest stage of the Laconian style. The glaze varies now between a washy brown for patterns and a hard shiny black for the plain portions of the ware. A custom was introduced, but sparingly practised, of painting the design in yellow-pink paint on a black ground, in which technique a considerable number of dedicatory inscriptions are found. The original leaf pattern of Laconian II., III., and IV., which is hardly used in V., has a fresh vogue in a form that is just recognisable (Fig. $9, a, b, c, e, f, m$ ), while the plates (Fig. 9, $k, l, n, o$ ), of which the rim is now wider and curved back, have

B.S.A. xiii. p. 134, Fig. ro.

${ }^{2}$ Cf. J.H.S. I908, p. 179. The suggestion made there is now fully confirmed by the evidence from the excavation of the site of Artemis Orthia.

${ }^{3}$ E.g. Munich Pinacothek, Neze Cat. Nos. 2257, 2259; Würzburg University Collection, No. 157 ; Berlin Antiquarium, Nos. 2038, 2039 ; Brussels, Musées royaux des arts décoratifs et industriels, No. A 1580 bis. 
departed even from the standard set up in the preceding period. As much may be said of the crescent pattern (Fig. 9, $l$ ), and the Gorgoneion (Fig. $9, p$ ) is now a very sketchy affair. The tongue pattern is rarely found, and a few debased scroll designs, due perhaps to Attic influence, make their appearance. With this the pottery that is distinctively Laconian reached its last stage.

'Jusqu' à présent rien n'autorise à croire que Sparte ait jamais eu une céramique originale de cette importance. La question (de l'origine des vases dits Cyrénéens) ne sera définitivement tranchée que si l'on trouve

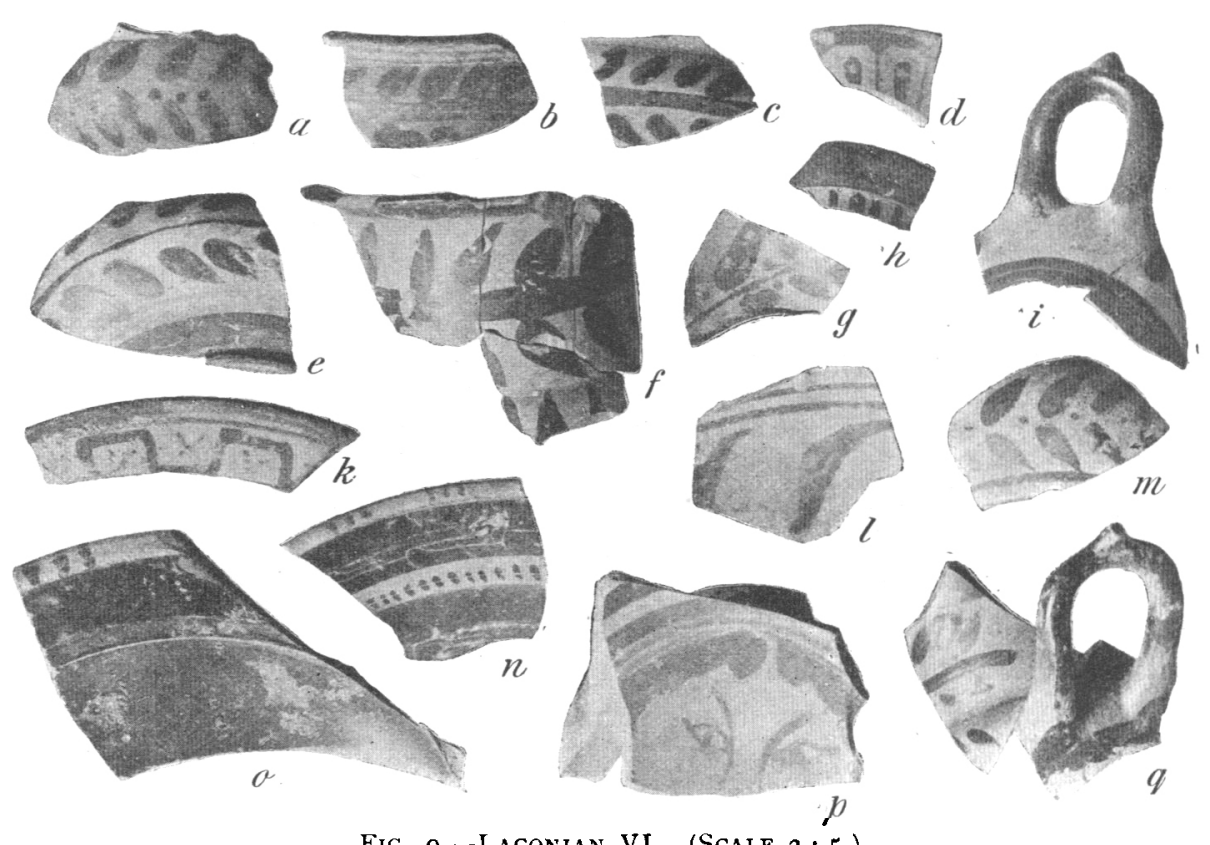

Fig. 9. - Laconian VI. (Scale $2: 5$.)

plus tard dans un de ces pays (Sparte, la Crète, Cyrène) une quantité notable de poteries à fond blanc.'

This prophecy is perhaps worthy of recollection now that the nature of the pottery made at Sparta has been ascertained. The convincing proof that that pottery is local to Sparta lies not only in its unbroken

1 Dumont and Chaplain, Les céramiques de la Grice propre, tom. i. p. 294. 
development from the Geometric Age, but also in the fact that it is found entirely alone, so that it is not possible to suppose that it was imported. This year also the fuller discovery of the nature of the ware of the sixth century makes it equally certain that the vases, of which the Cyrenaic origin has been till now generally accepted, were really made in Laconia during this period.

With regard to the two vases, which have been thought to make the attribution to Cyrene certain, the Arkesilas kylix in the Bibliothèque Nationale may easily, in the light of our new knowledge, be understood merely as a proof of those very close trade relations between Sparta and Cyrene which it is only natural to suppose existed. As for Studniczka's interpretation ${ }^{1}$ of the scene on the British Museum vase (B. 4) as the

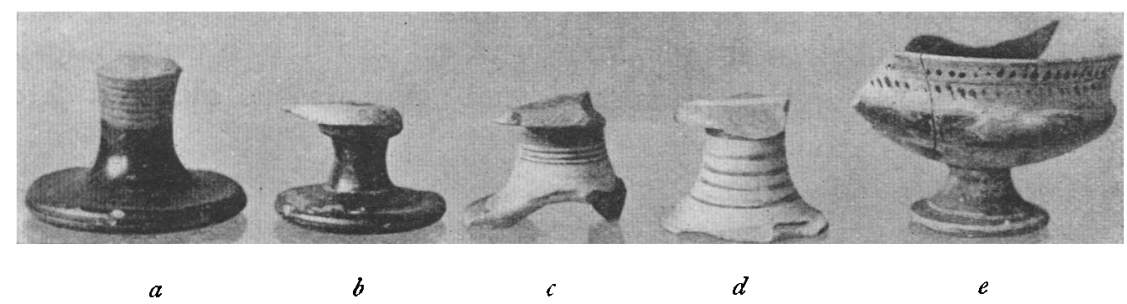

Fig. Io.-Stems of Kylikes of Laconian II. $(c, d, e)$, And Laconian V. $(a, b)$. (SCALE I : 3.)

nymph Cyrene with the silphion, I submit that the bough which the female figure is carrying is not in the least like the silphion, and can hardly be taken as a conventionalised representation of it, for it is clearly compounded of the three favourite Laconian patterns, namely the lotus, the pomegranate, and the leaf pattern.

To date this mass of pottery comparatively was easy: its actual dating presented more difficulty. The grounds, however, on which the beginning of the Orientalising style (Laconian I.) was fixed last year remain good, but the earlier date now proved for the introduction of the sand, together with the presence of the more developed style of Laconian II. coming immediately before that introduction, makes it clear that the first Laconian style cannot have lasted unmodified for a longer period than fifty or seventy years. The new date for the sand follows

\footnotetext{
1 Studniczka, Kyrene, p. 17.
} 
from that arrived at for Laconian III., which, if we accept the general conclusion that the Arkesilas of the vase (which falls easily into the latter part of that period) was the second of the name, must be put to the first half of the sixth century; this date, besides being likely on the mere grounds of style, agrees well with the discovery of a sherd of this style at Daphnai, ${ }^{1}$ which, if we may believe the historical evidence, must have been imported thither before 565 B.C. The dating of the later periods is more uncertain; but the Hellenistic ware which finally supplants the Laconian style can be dated by the evidence both of style and inscriptions to the latter half of the fourth century, while there is nothing in the painted inscriptions on vases of Laconian VI., mentioned above, to prevent the assignment of that style to the later fifth and earlier fourth century.

In my opinion, the greater number of the vases hitherto known fall into Laconian IV., though some must be placed to Laconian III. and V. ${ }^{2}$ It should be possible to fit the known vases into the Laconian series with some accuracy, and an interesting study may also be made of Attic imitations of the Laconian style.

J. P. DRoOP.

\section{THE LACONIAN STYLE.}

LACONIAN I. (700-625).

Shapes.-Skyphos, bowl, lakaina, plate, high cup with wide mouth.

Patterns. - Dot and square, rays, cross design on base.

Fabric.-Slip all over. Black and purple paint.

LACONIAN II. (625-600).

Shapes.-Skyphos, lakaina, plate, high cup with wide mouth, kylix, oinochoe.

1 Tanis, ii. Plate XXXII. 3, pp. 52 and 59.

I take this opportnnity of expressing my thanks for the facilities which I received for the study of 'Cyrenaic' pottery to the authorities of the British Museum, of the Ashmolean Museum at Oxford, of the Louvre, and the Bibliothèque Nationale, of the Musées royaux des arts décoratifs et industriels at Brussels, of the Königliche Museum at Cassel, of the Antiquarium at Berlin, of the Alte Pinacothek at Munich, of the collections belonging to the Universities of Bonn, Heidelberg, and Wiirzburg, and of the k. k. Oesterreich. Museum at Vienna. 
Patterns.-Leaf and bough, dot and square, rays, chequers, tongues, lotus, pomegranate (these two in early form), chevron, zigzag. Silhouette animals and birds. Rarely figures incised.

Fabric,-Slip all over. Black and purple paint.

LACONIAN III. (600-550).

Shapes.-Plate, lakaina, oinochoe, kylix, bowl.

Patterns.-Rays, dots, lotus, pomegranate, z, zigzags, leaf, bough, chevrons, wedges, dashes, tongues, rosette on base. Birds, beasts, and figures incised.

Fabric.-Slip all over (one example of partial disuse of slip). Black, purple and occasionally, white paint.

LACONIAN IV. (550-500).

Shapes.-As Laconian III.

Patterns.-As Laconian III.

Fabric.-Bad quality of slip, and carelessness of painting. Partial disuse of slip.

LACONIAN V. (500-425).

Shapes.-As Laconian III. and IV.

Patterns.-Crescent added, rays less frequent, pattern of slanting lines on raised ridge adopted for plate rim. Otherwise as Laconian III. and IV., but degenerated. Rosette and cross design on base.

Fabric.-Complete abandonment of slip. Purple paint rare as ornament, but kept for figure details, for which white is now much used. Inferior quality of black.

LACÓNIAN VI. (425-350).

Shapes.-Plate, bowl, kylix, oinochoe.

Patterns. - Leaf pattern debased, crescents, dots (those on rim of plate replace slanting lines of $\mathrm{V}$.). No figures.

Fabric.-No slip. Black paint. 
B.S.A., Vol. XIV. (1907-8), PI. III.

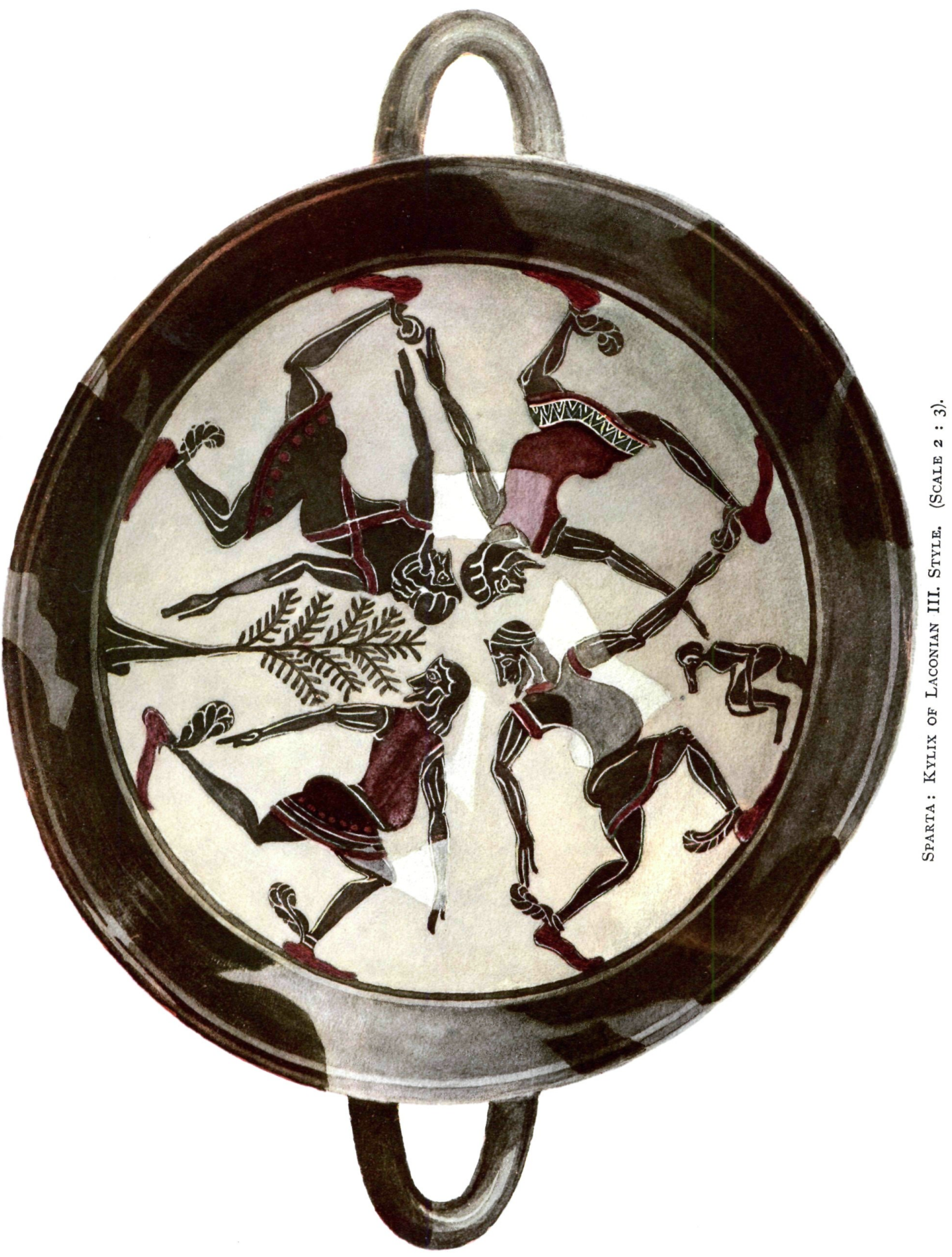


B.S.A., Vol. XIV. (1907-8), PI. IV.

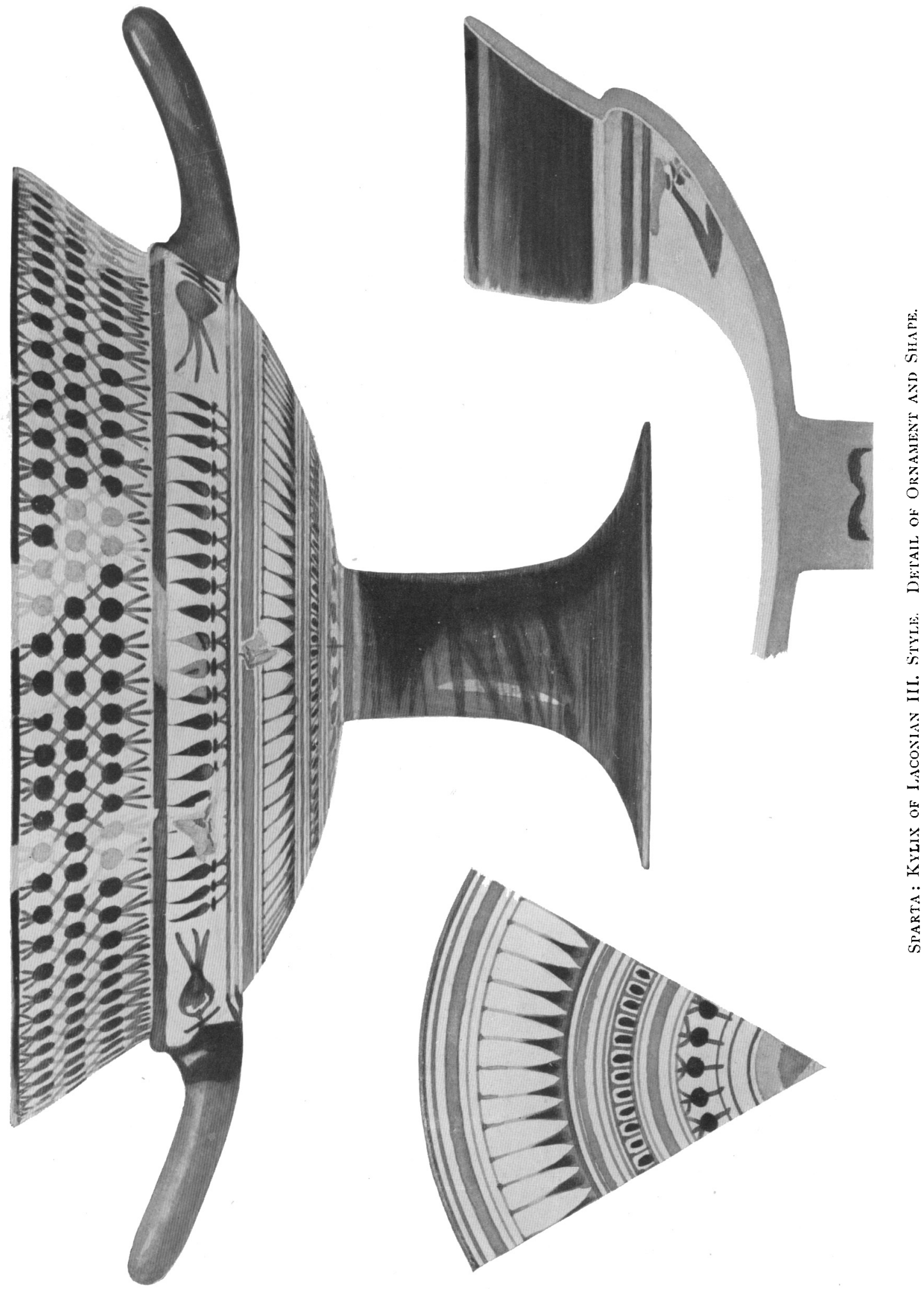

